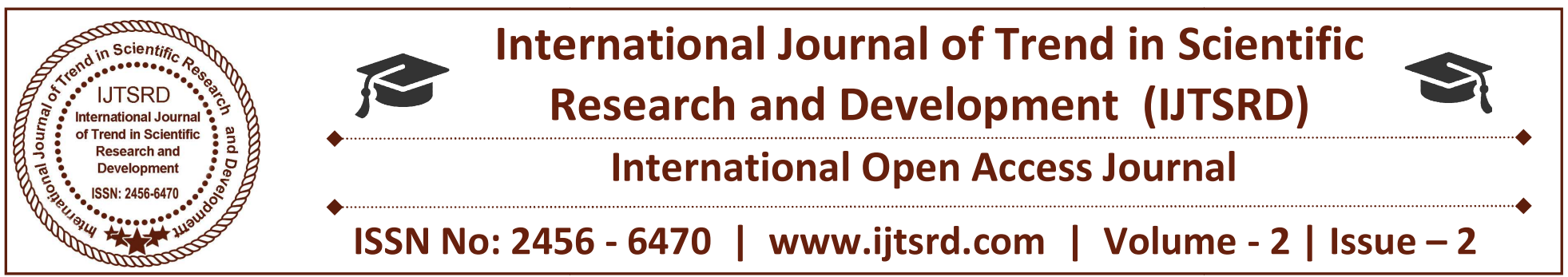

\title{
Bayesian Analysis to the Experiences of Corruption through Artificial Intelligence
}

\author{
Erica Pascual-Garcia \\ Division of Postgraduate Studies, \\ Sierra Sur University, Maxico
}

\author{
Guillermo De la Torre-Gea \\ Division of Postgraduate Studies, \\ Sierra Sur University, Maxico
}

\section{ABSTRACT}

In a democracy, the link between government and society is fundamental to prevent corruption and to ensure the functioning of mechanisms for transparency, accountability of the guaranteeing bodies and access to information. This is why the State implements public policies on transparency. However, corruption has been a phenomenon that is present in the Public Administration and has not been able to diminish with these policies. The objective of this study is to analyze the variables on the perception of corruption in society using the Bayesian method. For this, the data were obtained from the National Institute of Statistics and Geography in the part of its portal National Survey on Quality and Government Impact 2015, in the section on corruption. For its later Bayesian analysis using the software ELVIRA through the algorithm K2.

Keywords: Transparency, accountability, corruption and Public Administration

\section{Introduction}

At present, it is essential to have effective mechanisms that encourage the honest and efficient use of public resources and government actions. In addition, at the same time, they strengthen the culture of legality, transparency, and accountability, as essential elements of the State Reform. However, corruption is a serious problem that has not been diminished despite the public policies on control and transparency that are being implemented. Likewise, it affects the effectiveness of institutions, breaches goals, and objectives in government programs, prevents the resolution of citizen demands, and at the same time generates distrust of citizens in their government and discontent with society. This has become, in the last decades, a pandemic in the areas of government (Diego, 2006).

In Mexico the levels of perception of corruption are alarming and the strategies implemented to reduce them have not had the expected results. In 2014 Mexico obtained a rating of 35 points out of 100 possible and the number 103 place in 175 countries (International Transparency, 2014). In this study, the objective was to analyze by means of the Bayesian method the variables on the perception of corruption of the society in the State of Oaxaca.

\section{Corruption Theory}

According to González (2005), corruption is acted by which a public official is driven to act in a different way to the normative standards of the system to favor particular interests in return for a reward. These rewards may be monetary or otherwise, and those who most frequently incur such rewards are those in a position of power. In addition, corruption occurs not only in the public sector but also in the private sector.

The phenomenon of corruption is complex and it has multiple causes and effects, from the simple act of an illicit payment to the endemic functioning of the political and economic system. In general terms, it is 
usually understood as any abuse of public power for private purposes (Del Castillo, 2008).

It should be mentioned that corruption is multidimensional because it involves moral dilemmas, economic incentives, personal benefits, professionalism in the administration of the State, size and effectiveness of the public sector, functioning of legislative and judicial institutions, access of citizens to information Public accountability, professionalization of public servants, among others (Solimano, 2008).

According to Villoria (2000), corruption can be found at four different levels: in the political regime, in politics, in public administration, and in the judiciary. As far as the political regime is concerned, experience shows that if political regimes are corrupt, public servants can be linked to and adapt to that regime.

The phenomenon of corruption in the Public Administration is present in all three levels and orders of government. This may be because public servants obtain benefits that benefit them or allow them certain privileges they might not otherwise have.

\section{Materials y method}

To perform this work, we used a computer with $6 \mathrm{~GB}$ of RAM and Windows 10 operating systems. For the modeling, we used the Elvira software version 0.162, to released the development of the Bayesian network model. Which describes the relationships among all variables studied.

A Bayesian network is a graphical representation of dependencies for probabilistic reasoning (OrtízVázquez et al., 2015); In which each node represents a variable, and each arc a probabilistic dependency, where the conditional probability of each variable is specified (De la Torre-Gea et al., 2011). The variable pointed to by the bow is dependent (cause-effect) of the one at the origin of the bow (Fernández, 2005).

For this study, the data were obtained from INEGI in the part of its portal National Survey of Quality and Government Impact (ENCIG) 2015, in the section on corruption. For its later Bayesian analysis using the software ELVIRA through the K2 algorithm, which according to Manzo-García et al. (2016) and Wang et al. (2006) has provided good results in its implementation as an analysis tool. The data were obtained from the survey of the corruption section, the questions and variables are as follows, as shown Table 1.

Table 1: Perception of Corruption

\begin{tabular}{|c|c|c|}
\hline Question & Answer & Variable \\
\hline $\begin{array}{l}\text { 1.- Mentions the } \\
\text { three most } \\
\text { important } \\
\text { problems: }\end{array}$ & $\begin{array}{l}\text { No }=0 \\
\text { Yes }=1\end{array}$ & \\
\hline $\begin{array}{l}\text { Poor } \\
\text { performance of } \\
\text { government }\end{array}$ & $\begin{array}{l}\text { No }=0 \\
\mathrm{Yes}=1\end{array}$ & Mal_des_Gob \\
\hline Poverty & $\begin{array}{l}\text { No }=0 \\
\text { Yes }=1\end{array}$ & Pobreza \\
\hline Corruption & $\begin{array}{l}\text { No }=0 \\
\text { Yes }=1\end{array}$ & Corrupción \\
\hline Unemployment & $\begin{array}{l}\text { No }=0 \\
\text { Yes = } 1\end{array}$ & Desempleo \\
\hline Insecurity & $=0$ & Ins_del \\
\hline $\begin{array}{l}\text { Poor } \\
\text { enforcement of } \\
\text { the law }\end{array}$ & $\begin{array}{l}\text { No } \\
\text { Yes }\end{array}$ & Mal_apli_ley \\
\hline $\begin{array}{l}\text { Poor quality of } \\
\text { public education }\end{array}$ & $\begin{array}{l}\mathrm{No}=0 \\
\mathrm{Yes}=1\end{array}$ & Baj-cal_edu \\
\hline $\begin{array}{l}\text { Poor care in } \\
\text { public health } \\
\text { centers }\end{array}$ & $\begin{array}{l}\mathrm{No}=0 \\
\mathrm{Yes}=1\end{array}$ & Mal_aten_salud \\
\hline $\begin{array}{l}\text { Lack of } \\
\text { coordination } \\
\text { between } \\
\text { different levels } \\
\text { of government }\end{array}$ & 0 & Falta_coord_gob \\
\hline $\begin{array}{l}\text { 2.- The corrupt } \\
\text { practices of the } \\
\text { Government } \\
\text { are: }\end{array}$ & \multirow{7}{*}{$\begin{array}{l}\text { 1. Very } \\
\text { Frequent } \\
\text { 2. Frequent }\end{array}$} & \\
\hline $\begin{array}{l}\text { 3.- How often do } \\
\text { you think } \\
\text { corruption } \\
\text { practices occur } \\
\text { in: }\end{array}$ & & \\
\hline $\begin{array}{l}\text { Public } \\
\text { universities? }\end{array}$ & & Univ_pub \\
\hline Cops & & Policías \\
\hline $\begin{array}{l}\text { Public } \\
\text { hospitals? }\end{array}$ & & Hos_pub \\
\hline $\begin{array}{l}\text { Presidency of } \\
\text { the Republic? }\end{array}$ & & Pres_rep_sec \\
\hline Businessmen? & & Empresarios \\
\hline
\end{tabular}




\begin{tabular}{|l|l|l|}
\hline $\begin{array}{l}\text { Governor of } \\
\text { your State? }\end{array}$ & $\begin{array}{l}\text { 9. Do not } \\
\text { know/do } \\
\text { not respond }\end{array}$ & Bgob_Edo \\
\cline { 1 - 1 } $\begin{array}{l}\text { Municipal } \\
\text { Presidencies? }\end{array}$ & & pres_mun \\
\hline Unions? & & Sindicatos \\
\cline { 1 - 1 } $\begin{array}{l}\text { Chambers of } \\
\text { Deputies and } \\
\text { Senators? }\end{array}$ & & Cam_dip_sen \\
\hline $\begin{array}{l}\text { Electoral } \\
\text { Institutes? }\end{array}$ & & \\
\hline $\begin{array}{l}\text { Judges and } \\
\text { Magistrates? }\end{array}$ & & Inst_Elec \\
\hline Political parties? & & Jue_mag \\
& & Part_Poli \\
\hline
\end{tabular}

The data to be used for the analysis of variables, is from the State of Oaxaca, in the year 2015. The Bayesian network analysis will be carried out in three stages according to García-Manzo, these are: a) Pretreatment, B) Processing, and c) Post-processing.

\section{Results y discussion}

According to Figures 1 and 2, the three most important problems that the State of Oaxaca faces today, according to the statistics are poverty, unemployment, and corruption. In addition, these variables are related to other variables that affect or are affected by these variables.

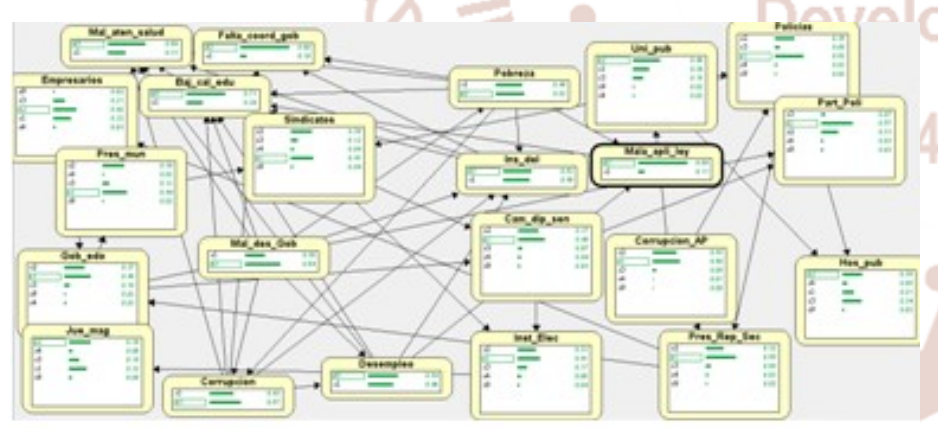

Fig 1: Bayesian perception of corruption in Oaxaca, 2015

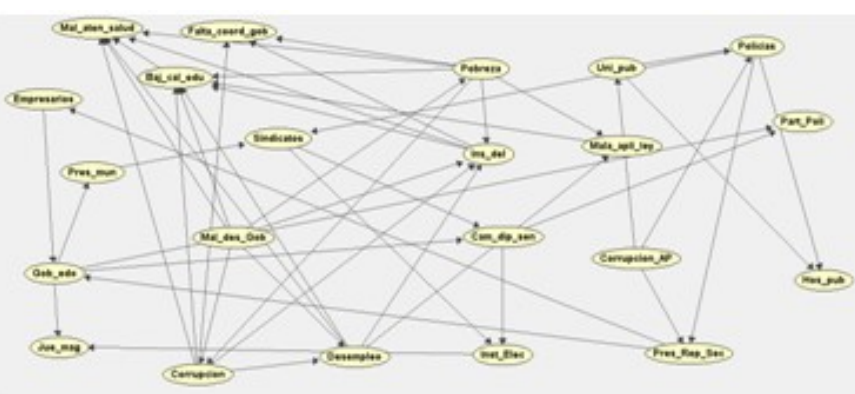

Fig 2: List of variables the main problems of the State and corruption in the Public Administration

In terms of poverty, according to the Bayesian network is related to the main variable that is the cause of the phenomenon. This variable is the poor performance of the government since the government is the main factor that intervenes through public policies to solve the problem of poverty, however, if these policies or programs are not well designed it is difficult to reduce and worse Eradicate the problem. In addition, poverty has effects such as poor health care, poor quality of education, corruption, insecurity and crime, poor enforcement and lack of government coordination.

In the same way, the unemployment variable is also related to other variables, unemployment is also caused by poor government performance and by corruption. Unemployment continues to be one of the main problems of the State of Oaxaca, due to the lack of creativity and sources of employment by the government, it is also a cause of corruption in the public and private sector (nepotism, godfathering, among others). Where many people are excluded without competing for positions. Likewise, unemployment has great effects, such as low quality of education and health, insecurity, and delinquency, poor enforcement of the law, due to the lack of mechanisms that strictly regulate these factors, since many occupy positions in which They are not fit or other people opt for the easier way (delinquency).

Corruption is also a serious problem that has not been diminished despite public policies implemented. It is also a problem that is affected or influenced by poor government performance and poverty. The problem of corruption is reflected by the low results obtained from the actions of the government, therefore, it also causes the poor quality of education, quality of health, lack of government coordination, insecurity and crime and unemployment.

Corruption in the public administration is one of the main evils of the state, $50 \%$ of the population surveyed said that these practices are very frequent in the state, so people no longer trust public institutions. Likewise, according to their perception, the institutions where corrupt practices occur frequently are: Political parties (57\%), Presidency of the Republic and its secretaries (55\%) and police (52\%) and in the institution according to the respondents Is less corruption is in unions, since unions defend workers' interests and is a counterweight to the state (see Figure 3). 
People no longer believe in political parties and are reflected in rates of abstention. Likewise, the Presidency of the Republic, its secretariats, including public security (police) is committed many acts of administrative, judicial and legal corruption. Figure 4 shows the relationships of the variables to the institutions where corruption practices also occur.

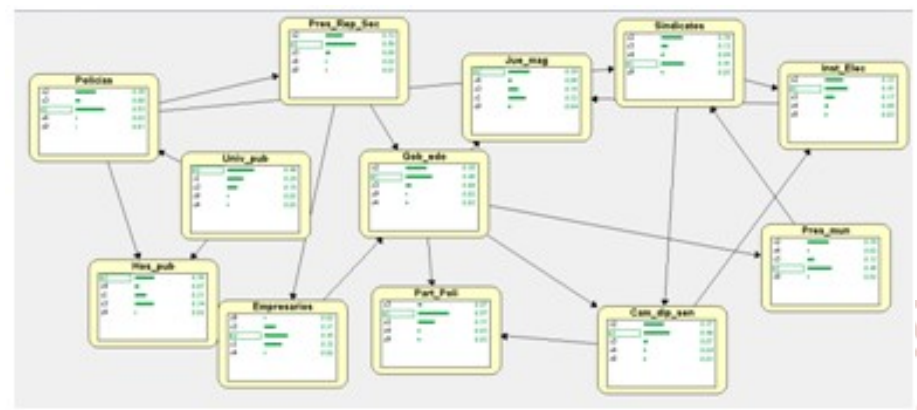

Fig 3: Bayesian network: inference of practices of corruption in institutions.

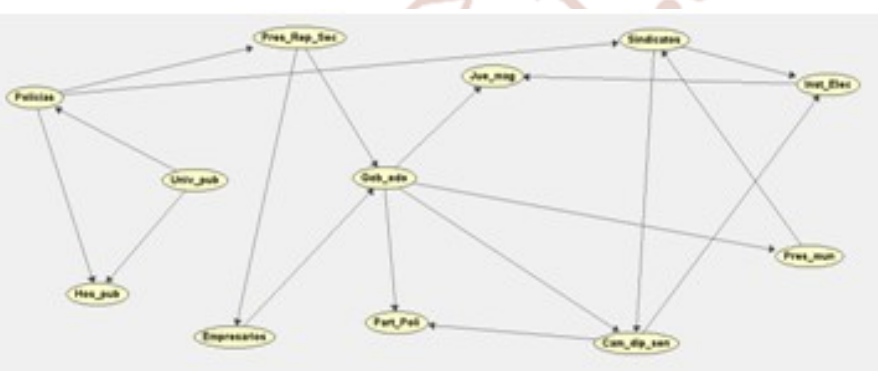

Fig 4: List of instructions variables where corruption practices occur.

In Figure 4, we showed that the variable of the State government is the one that most closely relates to the other variables, because it is directly influenced by the presidency of the Republic and by the secretaries, that is, the State Has to be adapted to the conditions of the federal scope. In addition, the private sector (entrepreneurs) that in some way intervenes in the decisions that the State takes and in turn also has a direct relation to the federal scope.

Therefore, the decisions taken by the state government are reflected in state institutions, as well as the chamber of deputies and senators and political parties which is the highest corruption index institution, which depends on the federal, state and chamber government Of Deputies and Senators and directly the municipal presidency is affected by the actions of the state government, that although it has autonomy, it continues to depend on the state and the federation. In this sense, municipalities are the first level of government where corruption practices are started directly.

The analysis shows a level of perception of corruption practically in all the analyzed institutions. As Casar (2015) points out, the levels of perceived corruption in institutions considered as the pillars of a representative democracy (political parties and legislative power) are extraordinarily high and this makes governance more difficult since it reduces legitimacy to government decisions.

In sum, the three variables (poverty, unemployment, and corruption) are related to each other. In addition, the main cause of these problems has been the poor performance of the government, since the actions and strategies in their public policies have not had the expected results. However, the other problems that for people are less important, are also related and are effects of the three most important. Likewise, public institutions where corruption practices occur do not apply strict mechanisms to reduce these rates and recover the legitimacy of citizenship.

\section{Conclusion}

The Bayesian network allowed us to analyze a large number of variables at a time and infer in specific situations. In this case, it was possible to analyze the three main problems and perception of corruption in Oaxaca and the relationship that the variables have with others. In this sense, the problems that Oaxaca has is due to the poor performance of the government, since its policies and programs have not been able to counter such problems. As for corruption, in all institutions, there are these practices, some with a higher index than others. However, they depend on the federal government and the Chamber of Deputies, since by hierarchical level they are the ones that establish the laws and mark the guidelines, but are the ones that more acts of corruption comment. As the theory says, if the regime is corrupt, institutions adapt, this is reflected in the statistics of the perception of people, who no longer trust institutions. It is a great challenge for the government to regain the legitimacy and confidence of its governed.

\section{References}

1. Casar, M.A. (2015). México: anatomía de la corrupción. Centro de Investigación y

2. Docencia Económicas A.C. (CIDE). 
3. De la Torre-Gea, G., Soto-Zarazúa, G., GuevaraGonzález, R., \& Rico-García, E. (2011). Bayesian networks for defining relationships among climate factors. International Journal of Physical Sciences, 6(18), 4412-4418.

4. Del Castillo, A. (2008). Medición de la corrupción: Un indicador de la Rendición de Cuentas. México: Serie: Cultura de la Rendición de Cuentas.

5. Diego Bautista, O. (2006). Marco institucional para establecer un dique internacional a la corrupción. Madrid: Cuadernos de Derecho Público núm. 29.

6. Fernández, E. (2005). Análisis de Clasificadores Bayesianos. Facultad de Ingeniería de la Universidad de Buenos Aires.

7. García-Manzo, G., De la Vega-Flatow, J. N., Martínez-Alcaráz, S. L., Quijada-López, R. M., Rodríguez-Reyes, C. S., \& De la Torre-Gea, G. A. (2016). Determination of relation-ship patterns in EEG and BVP signals using the K2 learning algorithm.

8. INEGI. (2015). Encuesta Nacional de Calidad e Impacto Gubernamental 2015. Estructura de la base de datos.
9. Ortiz-Vazquez IC, Pérez-Robles JP, FernandezLoyola R, Pérez-Brito JF, De La Torre-Gea GA. A multivariable computational fluid dynamics analysis method based in Bayesian networks applied in a bioreactor. Journal of Applied Chemical Science International. 2015;6(1):10-17.

10. Transparencia Internacional. (2014). Corruption Perception Index Brochure.

11. Solimano, Andrés (2008b). "La corrupción: motivacionesindividuales, fallas del Estado y desarrollo". En Andrés Solimano, Vito Tanzi y Felipe del Solar. Las termitas del Estado. Ensayos sobre corrupción, transparencia y desarrollo. Chile: F.C.E, Ciglob.

12. Villoria Mendieta, Manuel (2000). Ética pública y corrupción: curso de ética administrativa. Madrid, Tecno Universitat Pompeu Fabra.

13. Wang $\mathrm{S}$, Li $\mathrm{X}$, Tang $\mathrm{H}$. Learning Bayesian networks structure with continuous variables. In $\mathrm{Li}$ et al. (eds). Lecture Notes in Computer Science, Heidelberg: Springer-Verlang. 2006; 448-456. 